\title{
Eğitim Seviyelerine Göre Genç İşsizliğinin Ekonometrik Analizi: Türkiye Örneği*
}

\author{
Mutlu AYDOS ${ }^{1}$, Çiğdem DEMİR TOKER ${ }^{2}$
}

Özet

Son yıllarda dünyada ve Türkiye'de genç işsizlik, çözülmesi gereken öncelikli bir sorun haline gelmiştir. Çalışmanın amacl, eğitim seviyelerine göre genç işsizliği üzerinde etkili olan faktörleri ortaya koymaktır. Bu amaç doğrultusunda eğitim seviyelerine göre genç işsizliği genelleștirilmiş sıralı logit modeli ile analiz edilmiștir. Veriler, TÜIK'in uyguladığı $2014-2016$ yıllarına ait hane halkı işgücü anketinden elde edilmiștir. Bağımlı değișken; eğitimsiz, ilköğretim, lise ve üniversite mezunu olmak üzere 4 kategoriden olușan eğitim seviyesine göre genç ișsizliği değișkenidir. Bağımsız değișkenler; bölge, cinsiyet, yaş, medeni durum, doğduğu ilde yaşama gibi demografik faktörlerin yanında, işverene başvurma, yakınlarından rica, ISSKUR'a başvurma ve özel istihdama başvurma gibi iş arama kanallarından ve iş tecrübesi değişkenlerinden oluşmaktadır. Elde edilen bulgulara göre; yakınlarından ricada bulunma haricindeki iş arama kanalları, eğitimli genç işsizlerin istihdam edilmesine olumlu katkıda bulunmamaktadır. Doğduğu ilde yaşayıp belirli bir sosyal çevreye sahip olan eğitimli gençlerin, diğerlerine göre işsiz olma olasılıkları daha düşük iken gelişmiş bölgelerde yaşayanların eğitimli genç işsiz olma olasılığı daha yüksektir. Ayrıca, kadınların erkeklere göre eğitimli genç işsiz olma olasılığının daha fazla olduğu, evlilerin bekarlara göre eğitimli genç işsiz olma olasılı̆̆ının daha düşük olduğu sonucuna ulaşılmıştır.

Anahtar Kelimeler: Genç İşsizlik, Eğitim, Genelleştirilmiş Sıralı Logit

Jel Kodu: C25, E24, I25

\section{Econometric Analysis of Youth Unemployment According to Education Levels: The Case of Turkey}

\begin{abstract}
In recent years, youth unemployment in the world and in Turkey, has become a priority problem to be solved. The aim of the study is to reveal the factors that affect young unemployment according to their education level. For this purpose, young unemployment was analyzed by generalized ordered logit model according to education levels. The data were obtained from the household labor force survey for 2014-2016, which was implemented by TURKSTAT. The dependent variable; young unemployment is variable according to the education level which is composed of 4 categories, uneducated, primary, high school and university graduates. Independent variables; demographic factors such as region, gender, age, marital status, living on the shore, as well as job search channels and work experience variables such as applying for an employer, request from relatives, applying for Turkish Employment Agency and applying for private employment. According to the findings obtained; Job search channels other than requesting relatives do not contribute positively to the employment of educated young unemployed people. Educated young people who live in the province of their birth and have a certain social environment are less likely to be unemployed than others, while those living in developed regions are more likely to be unemployed. In addition, it was concluded that women are more likely to be unemployed educated young than men, and married young people are less likely to be unemployed than single.
\end{abstract}

Keywords: Youth Unemployment, Education, Generalized Ordered Logit.

Jel Codes: C25, E24, I25

ATIF ÖNERİi (APA): Aydos, M., Toker, Ç.D. (2021). Eğitim Seviyelerine Göre Genç İşsizliğinin Ekonometrik Analizi: Türkiye Örneği. İzmir İktisat Dergisi. 36(1). 109-126. Doi: 10.24988/ije.202136108

* Yüksek Lisans tezinden üretilmiștir.

${ }^{1}$ Doktora Öğrencisi, Süleyman Demirel Üniversitesi İktisadi ve İdari Bilimler Fakültesi, ISPARTA,

EMAIL: mutlu_aydos@hotmail.com ORCID: 0000-0002-6921-9292

2 Dr. Öğr. Üyesi, Akdeniz Üniversitesi İktisadi ve İdari Bilimler Fakültesi, ANTALYA,

EMAIL: demircigdem@akdeniz.edu.tr ORCID: 0000-0003-3291-3085 


\section{AYDOS - Ç. DEMIR TOKER}

\section{Gíriş}

Son yıllarda, dünya genelinde toplam işsizlik içerisinde gençlerin oranı giderek artmaktadır. $\mathrm{Bu}$ durum, genç işsizlik kavramının üzerinde durulması gereken küresel bir mesele olduğunun göstergesidir. Özellikle genç nüfus yoğunluğu fazla olan ülkelerin genç işsizlikle mücadele etmesi, ülke geleceği açısından oldukça önem arz etmektedir. Son yıllarda gerçekleşen ekonomik büyümeler, istihdam sağlayan nitelikte olamamaktadır. Yeni yatırımlar ve yeni iş imkanları sağlamayan bir ekonomik büyüme ile sürdürülebilir bir ekonomik kalkınma gerçekleșemez.

Yaşanan genç işsizlik sorunu yalnızca ekonomik olumsuzluklardan kaynaklanmamaktadır. Mevcut eğitim sisteminin 21. yüzyll yetkinliklerine uygun eğitim verememesi, genç işsizliğini arttıran en önemli unsur olarak görülmektedir. Üniversitelerin nitelik olarak değil nicelik olarak artması, yeterli bilgi ve beceriye sahip olmayan gençlerin işgücü piyasasına katılmasına neden olmaktadır. Mevcut eğitim sisteminin yetiştirdiği işgücü ile iş piyasasında aranan nitelikler arasında bir uyumsuzluk söz konusudur. $\mathrm{Bu}$ nedenle işverenler istihdam edecekleri kişilerin iş konusunda tecrübeli olmasını tercih etmekte, tecrübesiz adaylara olumsuz yaklaşmaktadır. Bu durum, gençlerin işgücü piyasasında dezavantajlı konumda bulunmalarına neden olmaktadır. Bilinçli gençler yetiştirmek, içinde bulunduğumuz bilgi çağının olmazsa olmazıdır. Eğitimde öğrencilerin niceliksel başarılarının yanında, yeteneklerinin ve becerilerinin geliştirilmesinin önemi günden güne artmaktadır (Baltaş, 2017). Eğitim sisteminden kaynaklanan sorunlar düzeltilmediği sürece, istihdam düzeyi arttırılsa bile ülke açısından sürdürülebilir bir kalkınma sağlanması mümkün görülmemektedir.

Gelişmiş ülkelerde çalışma, yalnızca ekonomik bir zorunluluk değil, aynı zamanda bireyin toplumda var olmasının bir gerekliliği olarak görülmektedir. Çalışmak bir yaşam tarzıdır ve bir işte istihdam edilmek kişinin kendine olan inancını artırmaktadır. Kişinin toplam üretime katkıda bulunması, kendine olan özsaygısını ve toplumun bireye saygısını güçlendirecektir. Çalışmak günümüzde en temel toplumsal haklardan biridir ve insana verilen değerin bir işareti olarak değerlendirilmektedir. Bireylerin niteliklerine uygun istihdam olanağ sağlanması toplumlar için oldukça önemlidir. Çünkü işsizlik diğer toplumsal sorunları doğuran önemli bir sorundur (Ören ve Şahverdioğlu, 2016: 19). Gençler, toplumun en dinamik kısmını oluşturmaktadır. Ülkelerin geleceği genç işgücüne ve genç işgücünün bilgi ve becerisine bağlıdır. İşgücü piyasasında gençlerin dezavantajlı konumda bulunmaları, birçok unsuru olumsuz etkilemektedir (Karabıyık, 2009: 303). Genç işsizliğinin sonuçları yalnızca bireye değil, aileye, topluma, ülkeye ve hatta ekonomiye dahi etki etmektedir.

İşsizlik, öncelikle en çok etkisini ekonomi alanında göstermektedir ve ardından sosyal ve psikolojik sorunları da beraberinde getirmektedir. İşsizlik gelir kaybı olarak gençlere ve ailelerine karşı mikro etkisini gösterirken, makro etkisini ekonomiyi etkileyerek göstermektedir. Gençlerin çalışmaması nedeniyle üretime katılamamaları, ülke ekonomisinde önemli kayıplara ve eksik istihdama neden olmaktadır (Murat ve Şahin, 2011: 35-36). İşsizlik yoksulluk riskine yol açmakta, yoksulluk da işsizliği artırmakta ve bu șekilde kısır bir döngü haline gelmektedir. İşsizlik nedeniyle gençlerde özgüven kaybı da meydana gelmektedir. Genç işsiz, işsizliği başarısızlık ve yenilgi olarak görmektedir. Bu düşünce genç bireyin ruh sağlığının bozulmasına ve davranışlarının farklılaşmasına neden olmaktadır. Ruhsal bozukluk, genç bireyin kendini işe yaramaz hissetmesine, tembellik hissinin artmasina ve bunun sonucu olarak toplumdan dișlanmasına neden olur. $\mathrm{Bu}$ durum bağımlılık yaratan maddelere eğilim ve suça yönelme ihtimalini artırmaktadır. Çünkü işsizlik, bireylerin toplumdan dışlanmasına ve bu nedenle toplumsal ve hukuki kurallara olan 
bağlılığının azalmasına neden olmaktadır. Sosyal yaşamdan uzaklaşan gencin, intihar eylemine yatkınlığı da işsizliğin bir sonucu olmaktadır. $\mathrm{Bu}$ konuda yapılan bazı araştırmalarda işsizlikten intihar eğilimine doğru bir nedensellik olduğu sonucuna varılmıştır (Bayraktar ve İncekara, 2013: 27; Karabiyık, 2009: 304).

Eğitilmiş, sağlıklı bir gençlik olmadan gelişim mümkün değildir. İşsizlik gençliğin toplumsal hayata katılımını güçleştirmektedir. Dışlanan bir gençlik, parlak bir geleceğin güvencesi olamaz. Çünkü dışlanan ve toplumun kenarında yaşayan gençlik, toplumda sorun yaratan, birliği bozan, düzene karşı çıkabilecek bir kesim anlamındadır. Toplumların gelişmesi gençliğin katılımı olmadan meydana gelemez. Sağlıklı, dinamik, iyi eğitilmiş, toplumda dinamik bir şekilde varlığını ortaya koyan gençlik toplumun gücü ve güvencesidir (Gündoğan, 1999: 71). Bir ülkenin eğitimli genç nüfusa gereken önemi vermesi ülkenin geleceği için önemlidir. Gençliğe yeterince yatırım yapamayan ülkelerin kalkınabilmesi mümkün olmamaktadır. Hal böyleyken, genç nüfusun işsizlikle mücadele etmesi gelecek hakkında umutların tükenmesine neden olmaktadır. Etkisi birçok noktada olumsuz sonuçlar doğuran genç işsizlik sorunu, bir an evvel çözülmesi öncelikli bir olgu haline gelmektedir. Bireyden başlayıp çı̆̆ gibi büyüyen sorunlara yol açan genç işsizliği ile mücadele etmek için hükümetin uygulayacağı istihdam politikaları bu konuda büyük önem arz etmektedir. Çalışmada, eğitim seviyelerine göre genç işsizliğini etkileyen faktörleri kesit veri analiziyle belirleyerek gençlerin yaşadığı sorunlara ışık tutmak amaçlanmıştır. Literatürde eğitimli genç işsizliği konusunda yeterli sayıda ampirik çalışmaya rastlanmadığından bu çalışmayla literatüre katkı sağlanacağı düşünülmektedir. Çalışmanın izleyen bölümlerinde ilk olarak, dünya ve Türkiye kapsamında genç işsizlik kavramı incelenmiştir. Sonrasında, genç işsizliği ile ilgili literatürdeki çalışmalara yer verilmiştir. Ardından, çalışmada kullanılan ekonometrik model açıklanmıştır. Son olarakta, genç ișsizliği etkileyen faktörlerin genelleștirilmiş sıralı logit yaklaşımı ile analizi neticesinde elde edilen bulgulara ve değerlendirmelere yer verilmiştir.

\section{DÜNYADA VE TÜRKIYE'DE GENÇ İŞSİZLİĞİNİN İNCELENMESİ}

Genç işsizliği, dünyada ve Türkiye'de oldukça önemli bir sorun olarak gündeme gelmektedir. Gençler için sağlanan istihdam fırsatlarının eksikliği, önemli bir küresel sorundur. Yetișkin işsizlik oranı \%4,3'tür. Genç işsizlik oranı \%13'lerde seyretmektedir ve yetişkin işsizlik oranından 3 kat daha fazladır (ILO, 2018: 2). Şekil 1'de yıllara göre küresel genç işsizlik sayıları ve oranları gösterilmektedir. 2016 yılı için küresel genç işsizlik oranı \%13 olarak tahmin edilmiştir. 2011 ve 2013 yılları arasında \%13,1'in altına düşse de 2017 ve 2018'de tekrar \%13,1'e yükselmiștir. Aynı zamanda, genç işsizlerin sayısı 20 yıldan fazla süredir ilk kez 2015 'te 70,3 milyonun altına düşmüştür. 2017'de genç işsizlerin sayısı 70,9 milyon olarak belirlenirken, bu durum 2009'daki 76,7 milyon genç işsize göre güçlü bir iyileşme olarak yorumlanmaktadır. (ILO, 2017: 15).

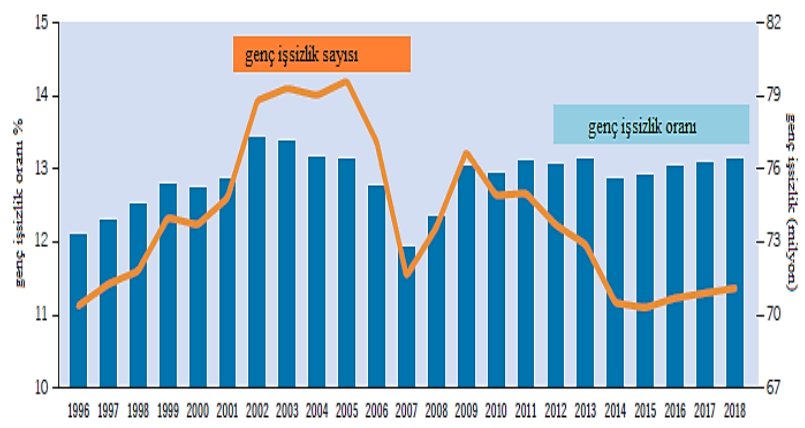

Şekil 1: Yıllara Göre Küresel Genç İşsizlik Sayıları ve Oranlar (ILO,2017: 15)

Dünyanın belirli bölgelerinde ve tüm dünyada 2000 ve 2017 yılları için karşılaştırılmalı genç işsizlik ve toplam işsizlik oranları Tablo 1'de verilmiștir. Dünya bankasının Mart 2017 verilerine göre dünyada genç işsizlik oranı 2000 yılında \%13,6 iken, 2017'de \%13,8'e ulaşmıştır. Dünya genelinde toplam ișsizlik oranı 2000 yılında \%6,4 iken, 2017'de \%5,8'e düşmüștür. Dünya genelinde genç işsizlik oranı toplam işsizlik oranının neredeyse iki 
katı kadardır. Bu da genç ișsizlik sorununun küresel boyutlara ulaştığının kanıtıdır.

Tablo 1: Dünya Genç İşsizlik ve Toplam İşsizlik Oranları

\begin{tabular}{|l|c|c|c|c|}
\hline & \multicolumn{2}{|c|}{ Genç İssizlik } & \multicolumn{2}{c|}{ Toplam İşsizlik } \\
\hline Bölgeler & $\mathbf{2 0 0 0}$ & $\mathbf{2 0 1 7}$ & $\mathbf{2 0 0 0}$ & $\mathbf{2 0 1 7}$ \\
\hline $\begin{array}{l}\text { Doğu Asya ve } \\
\text { Pasifik }\end{array}$ & 10,9 & 11,2 & 4,6 & 4,4 \\
\hline $\begin{array}{l}\text { Orta Doğu ve } \\
\text { Kuzey Afrika }\end{array}$ & 27,2 & 29,6 & 12,7 & 10,9 \\
\hline $\begin{array}{l}\text { Güney Asya } \\
\text { Sahra Altı Afrika }\end{array}$ & 13,8 & 12,9 & 8,3 & 7,5 \\
\hline $\begin{array}{l}\text { Euro Bölgesi } \\
\text { Arap Dünyası }\end{array}$ & 19,4 & 22,4 & 9,5 & 9,4 \\
\hline $\begin{array}{l}\text { Latin Amerika ve } \\
\text { Karayipler }\end{array}$ & 17,3 & 19,0 & 10,8 & 8,8 \\
\hline $\begin{array}{l}\text { Az Gelişmiş } \\
\text { Ülkeler }\end{array}$ & 9,7 & 10,6 & 5,1 & 5,4 \\
\hline Kuzey Amerika & 9,5 & 10,3 & 4,3 & 5,1 \\
\hline Avrupa Birliği & 19,9 & 19,5 & 9,3 & 8,0 \\
\hline Dünya & 13,6 & 13,8 & 6,4 & 5,8 \\
\hline
\end{tabular}

(ILOSTAT veri tabanı Dünya Bankası verileri, 2017)

Gelişmiş ve gelişmekte olan 19 ülkeden ve Avrupa Birliği'nden oluşan G-20 platformu, dünya ekonomisinin \%83'ünü oluşturan küresel ve bölgesel güçleri bir araya getirmektedir (Ayan, 2014: 10). Dünya Bankası'ndan elde edilen G-20 ülkelerine ait 2000 ve 2017 yılı genç işsizlik ve toplam işsizlik oranları Tablo 2' de gösterilmiştir. Türkiye'nin genç işsizlik oranı 2000 yılında 13,1 ve 2017 yılında 20,5 olarak hesaplanmıștır. Diğer ülkelerle karşılaştırıldığında Türkiye'nin 2000 yılı genç işsizlik oranının ortalamanın altında kaldığı gözlenmektedir. 2017 yılı genç işsizlik oranlarına bakıldığında ise Brezilya, Endonezya, İtalya, Suudi Arabistan ve Güney Afrika ülkeleriyle birlikte Türkiye'de de çok ciddi seviyede artış olduğu dikkat çekmektedir. Tablo 2'deki tüm ülkelerde genç işsizlik oranı, toplam işsizlik oranından fazladır. Almanya dışındaki gelişmiş ülkelerde genç işsizlik az da olsa artış göstermiştir. Gelişmekte olan ve ekonomik sıkıntılar yaşayan ülkelerde genç işsizlik oranının 2000 yllından 2017'ye artışı daha fazladır.

Tablo 2: G-20 Ülkelerinin Genç ve Toplam İşsizlik Oranları

\begin{tabular}{|c|c|c|c|c|}
\hline \multirow{2}{*}{ Ülkeler } & \multicolumn{2}{|c|}{ Genç İşsizlik } & \multicolumn{2}{|c|}{ Toplam İşsizlik } \\
\hline & 2000 & 2017 & 2000 & 2017 \\
\hline Avustralya & 12,1 & 12,5 & 6,3 & 5,7 \\
\hline Arjantin & 28,5 & 22,1 & 15,0 & 8,1 \\
\hline Brezilya & 18,1 & 29,9 & 13,9 & 13,4 \\
\hline Kanada & 12,6 & 12,9 & 6,8 & 6,6 \\
\hline Endonezya & 18,1 & 19,0 & 6,1 & 5,6 \\
\hline Çin & 9,7 & 10,8 & 4,5 & 4,6 \\
\hline Meksika & 5,0 & 7,3 & 2,6 & 3,8 \\
\hline Hindistan & 10,0 & 10,2 & 4,3 & 3,6 \\
\hline Rusya & 20,7 & 14,6 & 10,6 & 5,3 \\
\hline Fransa & 21,4 & 23,7 & 10,7 & 9,9 \\
\hline Almanya & 8,6 & 6,1 & 7,9 & 3,8 \\
\hline Japonya & 9,1 & 4,2 & 4,7 & 2,9 \\
\hline İtalya & 31,4 & 63,6 & 10,8 & 11,6 \\
\hline Güney Kore & 10,8 & 10,0 & 4,4 & 3,7 \\
\hline Suudi Arabistan & 24,4 & 32,6 & 4,6 & 5,5 \\
\hline Güney Afrika & 44,2 & 54,2 & 26,7 & 27,3 \\
\hline Birleşik Krallık & 12 & 12,1 & 5,6 & 4,7 \\
\hline $\mathrm{ABD}$ & 9,2 & 10 & 4,0 & 4,9 \\
\hline Avrupa Birliği & 19,9 & 19,5 & 9,3 & 8,0 \\
\hline Türkiye & 13,1 & 20,5 & 6,5 & 11,4 \\
\hline
\end{tabular}

( ILOSTAT veri tabanı Dünya Bankası verileri, 2017)

Dünya genelinde olduğu gibi ülkemizde de genç işsizliğinin artması, mevcut işgücü için yeterli istihdam olanaklarının yaratılamamasından kaynaklanmaktadır. Yıllar içinde ekonominin yaşadığı değişimler, toplam işsizlik ile genç işsizliğini çok yakından etkilemektedir.

Şekil 2'deki grafikte Türkiye'nin 2000- 2017 yılları arasındaki genç işsizlik oranları gösterilmiştir. Kasım 2000 ve Şubat 2001 krizleri arka arkaya Türkiye ekonomisinde önemli etkilere yol açmıştır. 


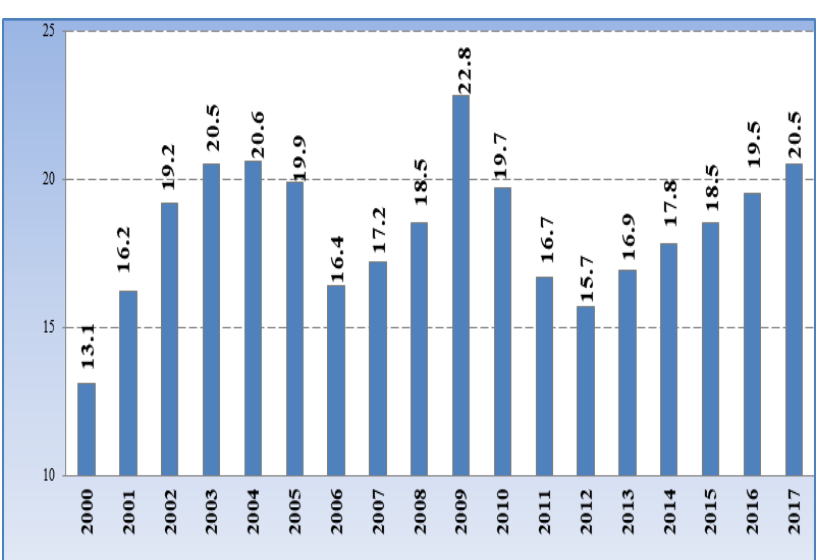

Şekil 2: Türkiye Genç İșsizlik Oranları (15-24) (ILOSTAT veri tabanı Dünya Bankası verileri,2017)

$\mathrm{Bu}$ etkilerden biri de toplam işsizlik ve genç işsizlik üzerinde görülmüştür. 2000-2004 döneminde genç işsizlik oranlarında artış yaşanmıştır. 2002 yılı genel seçimiyle birlikte Türkiye'de siyasi istikrar sağlanmıștır ve siyasi istikrarın ekonomi üzerinde etkileri görülmeye başlanmıştır. 2002 yılından itibaren yaşanan ekonomik büyüme, 2005 yllında \%8-9'ları aşan bir performans sergilemiştir. 2004'ten 2006 yılına kadar genç işsizlik oranında yaşanan düşüş ekonomide yaşanan büyümeyle ilişskilendirilebilmektedir. 2005 yılında yaşanan ekonomik büyüme performansl, 2005'ten sonraki 3 yll boyunca giderek yavaşlamıştır. 2009 yılında yaşanan küresel kriz, Türkiye ekonomisinde \%4,8 daralmaya sebep olmuştur. Bu gelişmeler neticesinde genç işsizlik oranı 2009'da 22,8 ile son 18 yılın en yüksek değerini almıştır. 20102011 yllarında ekonomik büyümenin \%9'un üzerinde gerçekleșmesi, kriz sonrasında çöküșe geçen Türkiye ekonomisinin toparlanmasına yardımcı olmuştur. Fakat 2012 ve sonrasında büyüme hızı yavaşlamıştır. Türkiye ekonomisinin son yıllardaki büyüme performansı potansiyel büyüme hızının altında kalmıştır (Sungur, 2015: 244-248). Bu durum çoğu iktisatçı tarafından "istihdam yaratmayan büyüme" olarak adlandırılmaktadır. Büyümenin her zaman işsizliği azaltmadığı, istihdam ve büyüme arasındaki ilişkinin karmaşık bir hal aldığ düşünülmektedir. $\mathrm{Bu}$ nedenle işsizlikle mücadelede çözümün yalnızca büyümeden beklenmemesi, ekonomik büyümenin istihdam sağlayabilir bir büyüme olmasının gerektiği düşünülmektedir (Ay, 2012: 330).

\section{LITERATÜR}

Dünyada ve ülkemizde işsizliğin ekonometrik analizlerle incelendiği birçok çalışma bulunmaktadır. İşsizliğin yanı sıra, son zamanlarda sıcça gündeme gelen genç işsizlik kavramı, üzerinde araştırmalar yapılan özel bir konu haline gelmekte ve bu konuyla ilgili yapılmış çalışmalar günden güne artış göstermektedir.

Lynch (1985), çalışmasında Britanya'daki genç işçilerin yeniden istihdam olasılıklarının belirleyicilerini maksimum olabilirlik yöntemi ile tahminlemiştir. Harris (1996), 1985-1988 yılları için Avustralya'daki genç işsizliğini probit modeli ile analiz etmiştir. Winkelmann (1996), Alman Sosyo-Ekonomik Panelinden elde edilen 1984-90 dönemi verilerini kullanarak, genç bireylerin Alman işgücü piyasasına girişini araștırmıştır. Riphahn (2000), lise sonrası okuldan ayrılan gençlerin eğitime devam etmelerini ve okuldan işgücü piyasasına geçişlerini incelemiștir. Mlatsheni ve Rospabe (2002), Güney Afrika'daki genç işsizlerin bazı özeliklerini araştırmışlardır. Narayan ve Smyth (2004), Avustralya'da bulunan genç erkek işsizler üzerine yaptıkları çalışmada suç oranları ile reel gelir arasındaki nedenselliği incelemişlerdir. Taşçı ve Tansel (2005), 2000 ve 2001 ylllarına ait hanehalkı işgücü anketini kullanarak, Türkiye'deki genç işsizliğin belirleyicilerini analiz etmişlerdir. Audas ve diğerleri (2005), 1994-1998 dönemi boyunca Macaristan'daki 3000'den fazla gencin işgücü piyasasındaki durumlarını gözlemlemişlerdir. Mroz ve Savage (2006), çalışmalarında genç işsizliğin uzun dönem etkisini incelemişlerdir. Choudhry vd. (2010), finansal krizlerin genç işsizlik oranı üzerindeki etkisini araştırmışlardır. Mütevellioğlu vd (2010), üniversiteli gençlerin gelecek kaygılarını Akdeniz Üniversitesinde yapılan bir alan araştırması ile incelemişlerdir. Sayın (2011), son yıllarda artan eğitimli genç işsiz sayısından yola çıkarak 1988-2010 yılları için 
Türkiye'de eğitim ve büyümenin genç işsizlik üzerindeki etkisini Vektör Otoregresif Modeli (VAR) ile analiz etmişlerdir. Çondur ve Bölükbaş (2014), Türkiye'de işgücü piyasası ve genç işsizlik- büyüme ilişkisini küreselleşme faktörünü dikkate alarak değerlendirmişlerdir. Günaydın ve Çetin (2015) çalışmalarında Türkiye ekonomisinde 1988-2013 dönemi için kişi başına reel gelir, ticari açıklık, enflasyon ve doğrudan yabancı sermayenin genç işsizlik üzerindeki etkisini araștırmışlardır. Bayrak ve Tatlı (2016), Türkiye'de kısa ve uzun dönem genç işsizliğini etkileyen bazı faktörleri belirlemişlerdir. Petreski vd. (2017) çalışmalarında, genç işsizlik süresini en çok etkileyen unsurun gençlerin çalışma tercihleri, iş ve yaşam tutumları olduğunu göstermiştir. Umoru ve Evelyn (2018), Nijerya'da işsizlik ve yoksulluk arasındaki bağlantıda eğitimin rolünü, ARDL yaklaşımı ile analiz etmişlerdir. Abdioğlu ve Albayrak (2018), 1988-2015 dönemi için Okun yasası doğrultusunda eğitim ve ekonomik büyümenin genç işsizlik üzerindeki etkisini belirlemeye çalışmışlardır.

\section{GENELLEŞTİRİLMIŞ SIRALI LOJİSTİK REGRESYON}

Bağımlı değişkenin sıralı nitel olduğu modellerde, bazen paralel eğimler varsayım ${ }^{3}$ sağlanamamaktadır. $\quad \mathrm{Bu}$ varsayımın sağlanamadığı durumda multinominal analiz teknikleri kullanılmaktadır. Fakat multinominal analiz teknikleri bağımlı değişkenin sıralı yapısını görmezden gelerek, sınıflı (nominal) bir yapıda olduğunu varsayar. $\mathrm{Bu}$ nedenle paralellik varsayımının sağlanmadığı durumlarda multinominal analizler kullanmak bilgi kaybına neden olmaktadır. $\mathrm{Bu}$ noktada paralel eğimler varsayımında esneklik sağlayan ve sıralı yapıyı dikkate alan yeni bir model önerilmektedir. Fu (1998), paralellik varsayımını sağlamayan birikimli logit modellerini kullanan Genelleştirlimiş Sıralı Logit modelini önermiştir. Bu modelde bağımsız değişkenin bağımlı değişkene fark oranı etkisi eşit olmamakta ve $\beta$ katsayısı bağımlı değişkenin her bir kategorisi için farkl tahmin edilmektedir (Arı ve Yıldız, 2014: 11, Fu, 1998:27). Eşik değerleri, bağımlı değişken kategorilerini iki gruba ayırır. İlk katsayı vektörü, en düşük kategori ve daha yüksek kategoriler olarak ikiye ayrılan modelden elde edilmektedir. İkinci katsayı vektörü, düşük olan ilk 2 kategori ile daha yüksek olan kategorilerin oluşturduğu modelden elde edilmektedir. Yani $j$-1'inci katsayı vektörü ilk kategoriden $j$-1'e kadar olanlar ile $j$ kategorisinin modellenmesi sonucunda elde edilmektedir. Genelleştirilmiş sıralı lojistik regresyonu, eş zamanlı $j$-1 adet lojistik regresyon modeli gibidir. Fakat bu modeller için kategoriler yukarıda belirtildiği gibi olmalıdır (Hilbe, 2009: 375).

Genelleştirilmiş sıralı logit modeli;

$$
\ln \left(\frac{\operatorname{Pr}\{y \leq j \mid x\}}{\operatorname{Pr}\{y>j \mid x\}}\right)=\tau_{j}-x \beta_{j}(1 \leq j<J)
$$

Burada $j$ bağımlı değişkenin sıralı kategorilerini, $x$ bağımsız değișkenler vektörünü, $\tau$ kesme noktasını (eşik değerini), $\beta$ ise logit katsayılar vektörünü ifade etmektedir. $\beta$ parametresindeki $\mathrm{j}$ indisi her bir bağımsız değișkenin katsayısının kesme noktalarına göre farklı tahmin edilebileceğini göstermektedir. Son ylllarda bu modelin kullanımı sosyal bilimlerde oldukça fazladır fakat diğer modellere göre fazla parametre tahmini yapıldığı için daha az etkindir (Fullerton ve $\mathrm{Xu}, 2012$ : 184).

$$
\begin{aligned}
& P\left(Y_{i}>j\right)=g\left(X \beta_{j}\right)=\frac{\exp \left(\alpha_{j}+X_{i} \beta_{j}\right)}{1+\left\{\exp \left(\alpha_{j}+X_{i} \beta_{j}\right)\right\}} \\
& j=1,2, \ldots, J-1
\end{aligned}
$$

$J$ sıralı bağımlı değişkenin kategori sayısıdır. $Y^{\prime}$ nin 1'den J'ye kadar her bir değeri için olasılıklar belirlenebilmektedir.

$$
P\left(Y_{i}=1\right)=1-g\left(X_{i} \beta_{1}\right)
$$
3 Paralel Eğimler Varsayımı, Bölüm 4.1'de
açılklanmıştır. 


$$
\begin{aligned}
& P\left(Y_{i}=j\right)=g\left(X_{i} \beta_{j-1}\right)-g\left(X_{i}\right) \quad j=2, \ldots, J \\
& P\left(Y_{i}=J\right)=g\left(X_{i} \beta_{J-1}\right)
\end{aligned}
$$

Bağımlı değişken kategorisi $J=2$ olduğunda, genelleştirilmiş sıralı logit modeli lojistik regresyon modeline eșittir. $J>2$ olduğunda, genelleştirilmiş sıralı logit modeli, bağımlı değişkenin kategorilerinin birleştirildiği bir dizi ikili logit modeline eşit olur. Örneğin; bağımlı değișkenin 4 kategoriden oluştuğu varsayılırsa $J=1$ için, 1.kategori diğerleri ile karşılaştırılır. $J=2$ için, 1 . ve 2 . kategoriye karşı 3. ve 4. kategoriler karşılaştırılır. J=3 için, 1. 2. ve 3. kategoriler 4. kategoriyle karşılaștırılır. $\mathrm{Bu}$ durumda Genelleştirilmiş sıralı lojistik regresyonda $\beta$ katsayıları $j^{\prime}$ nin bazı değerleri için aynı tahmin edilirken, diğerleri için farklı tahmin edilebilmektedir (Williams, 2006: 59).

\subsection{Paralel Eğimler Varsayımının Test Edilmesi}

Sıralı lojistik regresyonda paralel eğimler varsayımı, modeldeki katsayıların bağımlı değişkenin kategorilerine göre sabit olup olmadığını ifade etmektedir. Bu varsayımın sağlanmaması, katsayıların yanlış tahmin edilip yanlış yorumlanması açısından önem arz etmektedir. $\mathrm{Bu}$ nedenle paralel eğimler varsayımının test edilmesi gerekmektedir.

$$
H_{0}: \beta_{1}=\beta_{2}=\cdots=\beta_{J-1}=\beta
$$

J adet kategoriye sahip bağımlı değişkenin, J-1 adet ikili lojistik regresyonun tahmin edilmesiyle elde edilen $\beta$ eğim katsayılarının birbirine eşitliği test edilerek, varsayım ile ilgili bilgiye ulaşllabilmektedir. Eğer katsayılar birbirine eşit ise paralel eğimler varsayımı sağlanmaktadır. Eşitsizlik söz konusu ise varsayım sağlanmamaktadır (Long, 1997: 141).

\subsection{Olabilirlik Oran Testi (Likelihood Ratio Test)}

Kısıtlı ve kısıtsız iki modelin tahmin edilen katsayılarının karşılaştırıldığı log olabilirlik fonksiyonuna dayanan bir testtir. $K(M-2)$ serbestlik dereceli, $\chi^{2}$ dağılımı gösteren bir testtir. $K$; bağımsız değişken sayısını, $M$; bağımlı değișkenin kategori sayısını ifade etmektedir. LR ki kare testi olarak da adlandırılır (Fullerton ve $\mathrm{Xu}, 2018$ : 187).

$$
L R=-2 \ln L_{1}-\left(-2 \ln L_{2}\right)=-2 \ln \left(\frac{L_{1}}{L_{2}}\right)
$$

$L_{1} \quad$ paralellik varsayımını sağlayan(kısıtlanmış) modeli, L2 paralellik varsayımını sağlamayan (kısıtlanmamış) modeli ifade etmektedir. Hipotezler aşağıda olduğu gibi kurulmaktadır. Temel hipotez katsayıların birbirine eşit olduğunu belirtmekte yani paralellik varsayımının sağlandığını ifade etmektedir.

$$
\begin{aligned}
& H_{0}: \beta_{1}=\cdots=\beta_{J-1} \\
& H_{1}: \beta_{1} \neq \cdots \neq \beta_{J-1}
\end{aligned}
$$

LR test istatistiği ile $\chi^{2}$ tablo değeri karşılaştırılarak karar verilir. Küçük örneklemlerde olabilirlik oran testi ve Wald testi farklı sonuçlar verse de asimptotik olarak eşittir (Fullerton ve Xu, 2018: 187; Kleinbaum ve Klein, 2010: 134).

\subsection{Brant'in Wald Testi}

Brant (1990) tarafından geliştirilen Wald testi, her bir değişken için paralel eğimler varsayımını test edebilmektedir. $J$ adet kategoriye sahip bağımlı değişkenden elde edilen, $J-1$ adet ikili logit modelinin tahmin edilen $\beta_{j-1}$ katsayılarının eşitliğini ve her bir değişken için tahmin edilen katsayıların eşitliğini test etmektedir. $J-1$ tane ikili logit modelinin tahmin sonuçları birleştirilir. $\hat{\beta}^{*}=$ $\left(\hat{\beta}_{1}^{\prime}, \hat{\beta}_{2}^{\prime}, \ldots, \hat{\beta}_{J-1}^{\prime}\right)^{\prime}$ ve $\hat{\beta}^{* \prime}$ nin varyans-kovaryans matrisi oluşturulur. Wald testi, $H_{0}: \beta_{1}=\cdots=$ $\beta_{J-1}$ temel hipotezi ile kurulur. $\mathrm{Bu}$ hipotez $H_{0}: D \beta^{*}=0$ olarak da gösterilmektedir.

$$
D=\left(\begin{array}{ccccc}
I & -I & 0 & \ldots & 0 \\
I & 0 & -I & \ldots & 0 \\
\vdots & \vdots & \vdots & \ddots & \vdots \\
I & 0 & 0 & \ldots & -I
\end{array}\right)
$$

Wald istatistiği;

$$
W=\left(D \hat{\beta}^{*}\right)^{\prime}\left[D \widehat{\operatorname{Var}}\left(\hat{\beta}^{*}\right) D^{\prime}\right]^{-1}\left(D \hat{\beta}^{*}\right)
$$

J-2 serbestlik derecesiyle $\chi^{2}$ dağılımlıdır. Bireysel değişkenler için hipotez, $H_{0}: \beta_{k 1}=$ 
$\cdots=\beta_{k, J-1} \quad$ olarak kurulmaktadır. Test edilecek katsayılara karşılık gelen satır ve sütunlar $\mathrm{D}, \widehat{\beta}^{*}$ ve $\widehat{\operatorname{Var}}\left(\hat{\beta}^{*}\right)$ matrislerinden seçilerek J-2 serbestlik derecesiyle test edilebilir (Long,1997:144).

Brant Testi,

$\delta_{1}=0 ; E\left(\tilde{\beta}_{j}\right) \approx \beta_{1}+\delta_{j} \beta_{1} \quad(j=1, \ldots, k-1)$ olarak kurulmaktadır. $\tilde{\beta}$, en çok olabilirlik yöntemiyle tahmin edilmiş katsayıdır. $\mathrm{Bu}$ ifade, $\tilde{\beta}$ için doğrusal olmayan regresyon denkleminin bir türüdür. $\delta_{j}=0$ testi, $\tilde{\beta}$ 'nın ters ağırlıklandırılmış varyans-kovaryans matrisinde $\tilde{\beta}$ 'nın ağırlıklandırılmış regresyonunun tahmin edilmesiyle oluşturulmaktadır. Test istatistiği;

$\chi^{2}=\hat{\delta}^{1} \hat{V}(\hat{\delta})^{-1} \hat{\delta}$

$(\hat{V}(\hat{\delta}) ; \hat{\delta}$ varyans-kovaryans matrisi) $\mathrm{k}-2$ serbestlik dereceli $\chi^{2}$ dağılımı gösterir (Brant,1990:1174). LR testi, tüm değişkenlerin katsayılarının eş zamanlı olarak eşitliğini test etmektedir. Buna göre, bazı değişkenlerin katsayılarının, diğer değişkenler farklıyken ikili denklemlere karşı özdeş olup olmadığı belirlenemez. Bu nedenle, Brant'ın Wald testi her bir değişken için paralel regresyon varsayımını ayrı ayrı test ettiği için daha kullanışlıdır. (Long ve Freese, 2001: 151).

\section{AMPÍRIKK ANALİZ}

\subsection{Veri Seti ve Değişkenler}

Çalışmada, Türkiye İstatistik Kurumu (TÜİK)'nun uygulamış olduğu hanehalkı işgücü anketinden elde edilen veriler kullanılmıştır. 2014, 2015 ve 2016 yıllarına ait anket verilerinden 15-29 yaş grubu işsiz bireyler seçilerek veri seti birleştirilmiştir. Gençler ile ilgili yapılan çalışmalarda belirlenen genç yaş aralı̆̆g, çalışmalara göre farklılık göstermektedir. Birleşmiş Milletler'in genç tanımı 15-24 yaş aralığını kapsamaktadır. Ancak Yentürk ve Başlevent'in (2007) çalıșmalarında belirtildiği üzere tüm dünyada ve Türkiye'de 15-24 yaş grubunun eğitimde kalma süresi uzamıştır. Ayrıca Avrupa Birliği, gençlik istatistiklerinde genellikle 15-29 yaş aralığını kullanmaktadır. Buradan hareketle bu çalışmada genç yaş aralığı 15-29 olarak belirlenmiştir. Ankete katılan bireylerin en son tamamladıkları okula göre eğitim seviyelerini belirleyen yanitlar; "bir okul bitirmeyen (0)"," ilkokul (1)", "ortaokul ve ilköğretim (2)", "genel lise (3.1)", "mesleki veya teknik lise (3.2)", "2,3 ve 4 yıllık eğitim veren yüksekokul veya fakülte (4)", "yüksek lisans (5 ve 6 yıllık fakülteler dahil) veya doktora (5)" olmak üzere 7 kategoriye ayrılmıștır. Bu kategorilerden bir kısmı, seviyelerinin eşit olması veya gözlem sayısının azlığı nedeniyle birleștirilmiştir. Eğitim seviyesi; "eğitimsiz (0)", "ilköğretim mezunu (1)", "lise mezunu (2)", "üniversite mezunu (3)" olmak üzere 4 kategori ile yeniden oluşturulmuştur. Eğitim seviyelerine göre genç işsiz bireylerin demografik özelliklerini belirten değişkenler ve iş arama kanalları ile iş tecrübeleri bağımsız değişkenler olarak modelde yer almıştır. Tablo 3'te analizde yer alan değişkenlerin betimleyici istatistikleri verilmiştir.

Tablo 3: Betimleyici İstatistikler

\begin{tabular}{|lll|}
\hline Değişken & Frekans(N) & Yüzde (\%) \\
\hline Eğitim Seviyesi & & \\
Ĕgitimsiz & 1.248 & 5,14 \\
İlköğretim & 9.061 & 37,31 \\
Üne & 6.566 & 27,04 \\
Bölgeler & 7.411 & 30,52 \\
Marmara & & \\
İç Anadolu & 6.100 & 25,12 \\
Ege & 4.232 & 17,43 \\
Akdeniz & 2.556 & 10,52 \\
Karadeniz & 3.077 & 12,67 \\
Doğu Anadolu & 2.255 & 9,29 \\
Güneydoğu & 2.544 & 10,48 \\
Anadolu & 3.522 & 14,50 \\
Cinsiyet & & \\
Kadın & & \\
Erkek & 9.994 & 41,25 \\
Yaş & 14.292 & 58,85 \\
15 & & \\
16 & 403 & 1,66 \\
17 & 686 & 2,82 \\
18 & 1.039 & 4,28 \\
19 & 1.543 & 6,35 \\
20 & 1.543 & 6,42 \\
21 & 1.597 & 6,58 \\
22 & 2.031 & 8,36 \\
23 & 2.248 & 9,26 \\
& 2.341 & 9,64 \\
\hline
\end{tabular}


Tablo 3: Betimleyici İstatistikler(Devamı)

\begin{tabular}{|c|c|c|}
\hline Değişken & Frekans(N) & Yüzde (\%) \\
\hline 24 & 2.250 & 9,26 \\
\hline 25 & 2.109 & 8,68 \\
\hline 26 & 1.908 & 7,86 \\
\hline 27 & 1.685 & 6,94 \\
\hline 28 & 1.513 & 6,23 \\
\hline \multicolumn{3}{|l|}{ Doğduğu İlde } \\
\hline Yaşama & 16.236 & 66,85 \\
\hline Doğduğu İlde & 8.050 & 33,15 \\
\hline \multicolumn{3}{|l|}{ Yaşayanlar } \\
\hline Doğduğu İlde & 19.645 & 80,99 \\
\hline Yaşamayanlar & 4.641 & 19,11 \\
\hline \multicolumn{3}{|l|}{ Medeni Durum } \\
\hline \multicolumn{3}{|l|}{ Bekar } \\
\hline \multicolumn{3}{|l|}{ Evli } \\
\hline \multicolumn{3}{|l|}{ Tecrübe } \\
\hline Yok & 20.554 & 15,37 \\
\hline Var & 3.732 & 84,63 \\
\hline \multicolumn{3}{|l|}{ Doğrudan } \\
\hline \multicolumn{3}{|l|}{ Başvurma } \\
\hline Başvuranlar & 16.645 & 69,72 \\
\hline Başvurmayanlar & 7.228 & 30,28 \\
\hline \multicolumn{3}{|l|}{ İŞKUR'a } \\
\hline \multicolumn{3}{|l|}{ Başvurma } \\
\hline Başvuranlar & 6.386 & 26,75 \\
\hline Başvurmayanlar & 17.487 & 73,25 \\
\hline \multicolumn{3}{|l|}{ Yakınlardan } \\
\hline \multicolumn{3}{|l|}{ Ricada Bulunma } \\
\hline Başvuranlar & 21.678 & 9,19 \\
\hline Başvurmayanlar & 2.195 & 90,81 \\
\hline \multicolumn{3}{|l|}{ Özel İstihdam } \\
\hline \multicolumn{3}{|l|}{ Kurumlarına } \\
\hline \multicolumn{3}{|l|}{ Başvurma } \\
\hline Başvuranlar & 5.411 & 22,67 \\
\hline Başvurmayanlar & 18.462 & 77,33 \\
\hline \multicolumn{3}{|l|}{ Yil } \\
\hline 2014 & 8.063 & 33,20 \\
\hline 2015 & 8.005 & 32,96 \\
\hline 2016 & 8.218 & 33,84 \\
\hline
\end{tabular}

Eğitim seviyesine göre veri setinin frekans dağılımı incelendiğinde, en fazla katılımın 9061 kişi ile ilköğretim mezunu genç işsizlerden oluştuğu görülmektedir. İkinci sırada 7411 kişi ile üniversite mezunu genç işsizler yer almaktadır. Eğitimsiz genç işsiz sayısı 1248 iken, lise mezunu genç işsiz sayısı 6566'dır. Genç işsizlerin bölge bazında oranları incelendiğinde \%25,12 ile en çok katılımın Marmara bölgesinden olduğu görülmektedir. Diğer bölgelerin katılımı ise; İç Anadolu bölgesi \%17,45, Ege bölgesi \%10,52, Akdeniz bölgesi \%12,67, Karadeniz bölgesi
\%9,29, Doğu Anadolu bölgesi \%10,48, Güneydoğu Anadolu bölgesi \%14,50'dir. Genç işsizlerin cinsiyete göre dağılımı \%41,25 oranında kadın, \%58,75 oranında erkek şeklindedir. Genç işsizlerin yaş dağılımı; 15-19 yaş grubu \%21,54, 20-24 yaş grubu \%43,10, 25-29 yaş grubu \%35,36'dır. Genç işsizlerin \%66,85'i doğduğu ilde yașamakta, \%33,15’i doğduğu il dışında başka bir ilde yaşamaktadır. Verinin \%80,99'u bekar genç işsizlerden, \%19,11'i evli genç işsizlerden oluşmaktadır. Genç işsizlerin \%15,37'i herhangi bir iş tecrübesine sahip değilken, \%84,63'ü bir iş tecrübesine sahiptir. İş aramada başvurulan kanallar, doğrudan bir işverene başvurma, IŞKUR'a başvurma, özel istihdam kurumlarına başvurma ve iş bulma konusunda genç işsizlerin yakınlarından ricada bulunmaları şeklinde belirlenmiştir. Doğrudan bir işverene başvurmayan gençlerin oranı \%30,28, başvuranların oranı \%69,72'dir. İȘKUR'a başvuranlar \%26,75, başvurmayanlar \%73,25 oranındadır. İş ararken özel istihdam kurumlarına başvuranlar \%22,67, başvurmayanlar ise \%77,33 oranındadır. İş bulma konusunda yakınlarından ricada bulunan gençlerin oranı \%90,81'dir. Buradan anlaşıldığı üzere, doğrudan işverene başvurma ve yakınlardan ricada bulunma, en yoğun bașvurulan iș arama kanallarıdır. İSKKUR ve özel istihdam ofislerinin genç işsizler arasında daha az tercih edilen iş arama kanalları olduğu görülmektedir.

Türkiye'nin coğrafi bölgelerinde eğitim seviyelerine göre genç işsiz dağılımı Şekil 3'te görülmektedir. Eğitimsiz genç işsiz sayısının tüm bölgelerde eğitimli genç işsiz sayısından düşük olduğu görülmektedir. Zorunlu eğitim sisteminin hayata geçirilmesi ve eğitim olanaklarının artması bu durumu açıklamaktadır. Eğitimli genç işsizler incelendiğinde, Marmara, İç Anadolu ve Karadeniz bölgelerinde diğer eğitim seviyelerine göre üniversite mezunu genç işsizlerin sayısının daha fazla olduğu görülmektedir. Ege, Akdeniz, özellikle Doğu ve Güneydoğu Anadolu bölgelerinde ilköğretim mezunu genç işsizlerin sayısının diğer eğitim 
seviyelerindeki genç ișsiz sayısından fazla olduğu görülmektedir.

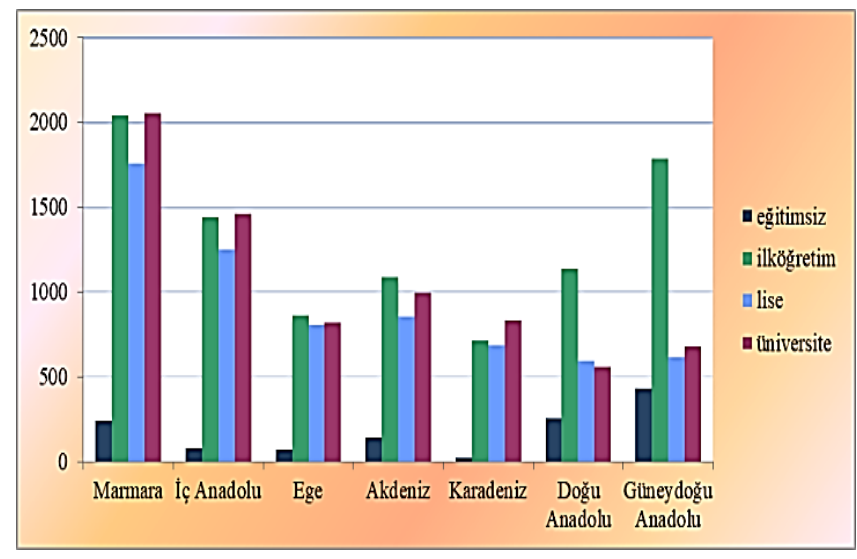

Şekil 3: Genç İşsizlerin Bölgelere Göre Eğitim Seviyeleri

\subsection{Yöntem ve Bulgular}

Modelde yer alan değişkenlerin açıklamaları Tablo 4'te verilmektedir. Bağımlı değişken, genç işsizlerin eğitim seviyeleri olarak belirlenmiş, bağımlı değişken kategorileri; eğitimsiz-ilköğretim-lise-üniversite mezunu genç ișsizler șeklinde sıralanarak oluşturulmuştur. Bağımsız değişkenler; bölge, cinsiyet, yaş, doğduğu ilde yaşama, medeni durum, iş tecrübesi, iş arama kanalları şeklindedir. Veriler 2014-2016 yıllarını kapsadığı için yılın etkisini görebilmek adına yıl faktörü kukla değişken olarak modele eklenmiştir. Analizde, öncelikle sıralı logit modeli tahmin edilmiş ve paralel eğimler varsayımı, olabilirlik oran testi ve Brant testi ile sınanmıştır. Bunun sonucunda, paralel eğimler varsayımının bazı değişkenler tarafından ihlal edildiğine ulaşılmıştır. Tahmin edilen modeldeki bazı eğim katsayılarının ve fark oranlarının bağımlı değişkenin kategorileri arasında farklılık göstermesi sonucunda alternatif bir model olan genelleştirilmiş sıralı logit model kullanılmıştır. $\mathrm{Bu}$ model, paralel eğimler varsayımı için esneklik göstermektedir. Elde edilen bulgular tablolar aracılığıyla sunulmuştur. Analiz, STATA 14 programı kullanılarak uygulanmıştır.

Tablo 4: Değișkenlerin Açıklamaları

\begin{tabular}{|c|c|c|c|}
\hline Bağımlı Değişken & Değişken Türü & \begin{tabular}{|l|} 
Temel Düzey \\
\end{tabular} & Kategoriler \\
\hline Eğitim Seviyesi & Siralı Nitel & Eğitimsiz & \begin{tabular}{|l|} 
Eğitimsiz \\
İlköğretim \\
Lise \\
Üniversite \\
\end{tabular} \\
\hline Bağımsız Değişkenler & Değișken Türü & \begin{tabular}{|l|} 
Temel Düzey \\
\end{tabular} & Kategoriler \\
\hline Bölge & Nitel & Marmara & $\begin{array}{l}\text { Marmara-İç Anadolu-Ege-Akdeniz-Karadeniz- } \\
\text { Doğu Anadolu ve Güneydoğu Anadolu }\end{array}$ \\
\hline Cinsiyet & Nitel & Erkek & Erkek-Kadın \\
\hline Yaş & Sürekli & & Yaș Grubu: $15-29$ \\
\hline Doğduğu İlde Yaşama & Nitel & Hayır & Evet-Hayır \\
\hline Medeni Durum & Nitel & Bekar & Bekar-Evli \\
\hline Tecrübe & Nitel & Yok & Var-Yok \\
\hline İş Arama Kanalları & & & \\
\hline Doğrudan İşverene Başvurma & Nitel & Hayır & Evet-Hayır \\
\hline İşkur’a Başvurma & Nitel & Hayır & Evet-Hayır \\
\hline Özel İstihdam Kurumlarına Başvurma & Nitel & Hayır & Evet-Hayır \\
\hline Yakınlarından Ricada Bulunma & Nitel & Hayır & Evet-Hayır \\
\hline Yll & Nitel & 2014 & 2014-2015-2016 \\
\hline
\end{tabular}

Tablo 5: Paralellik Varsayımı Test Sonuçları

\begin{tabular}{|l|c|c|c|}
\hline & $\begin{array}{c}\text { Ki-kare } \\
\text { istatistiği }\end{array}$ & $\begin{array}{c}\text { Serbestlik } \\
\text { derecesi }\end{array}$ & p-değeri \\
\hline $\begin{array}{l}\text { Olabilirlik } \\
\text { oran testi }\end{array}$ & 1179,81 & 34 & 0,000 \\
\hline Brant testi & 1153,50 & 34 & 0,000 \\
\hline
\end{tabular}

Siralı logit modelinin temel varsayımı olan paralel eğimler varsayımı, olabilirlik oran testi ve brant testi ile sinanmaktadır. Tablo 5'teki sonuçlar incelendiğinde test istatistikleri istatistiksel olarak anlamlıdır ve $0,000<0,05$ olması nedeniyle, paralel eğimler varsayımının 
sağlandığını belirten temel hipotez \%5 önem düzeyinde reddedilmektedir. Olabilirlik oran ve Brant testlerine göre, model paralel eğimler varsayımını ihlal etmektedir.

$\mathrm{Bu}$ nedenle sıralı logit tahmin sonuçları geçersiz olup, diğer alternatif model olan Genelleștirilmiş Sıralı Logit Modeli ile tahminler yapılmıştır. Bu modellerin tahmini, bağımlı değişken kategorilerinin ikili gruplandırılarak ayrı ayrı ikili (binary) logit modellerinin tahmin edilmesiyle yapılmaktadır. Yazılım programında, genelleştirilmiş sıralı logit modeli tahmin edilmeden önce paralel eğimler varsayımını bozan değişkenler Wald testi ile tespit edilmektedir. Daha önce yapılan Brant testinde tüm değişkenlerin tek tek paralellik varsayımını sağlayıp sağlamadıkları sınanmaktadır. Tüm değişkenler için bu testlerin sonuçları Tablo 6'da verilmiştir. Her iki test sonucuna göre, Akdeniz bölgesi, işverene başvurma, yakınlardan rica değişkenleri ve 2016 yıl kukla değişkeni paralel eğimler varsayımını sağlamakta, diğer değişkenler bu varsayımı bozmaktadır. Genelleștirilmiş sıralı logit modeli tahmin sonuçları Tablo 7' de verilmiştir. Paralel eğimler varsayımını sağlamayan değişkenler için her modelde farklı katsayı ve fark oranları tahmin edilmiștir ve Tablo 7'de koyu renkle gösterilmiștir. Bağımlı değișkenin 4 kategoriden oluşması nedeniyle, 3 ayrı logit model tahmin edilmektedir. Burada, varsayımı bozan değişkenler için her modelde farklı katsayı ve fark oranı tahmin edilirken, paralellik varsayımını sağlayan değișkenler için her modelde aynı katsayı ve fark oranı tahmin edilmektedir. Model 1'in bağıml değişken kategorileri eğitimsizler (0) ile eğitimliler (ilköğretim, lise ve üniversite mezunları (1)); model 2'nin bağımlı değişken kategorileri eğitimsizler ve ilköğretim mezunları (0) ile lise ve üniversite mezunları (1); model 3'ün bağımlı değişken kategorileri lise ve altı eğitim seviyeleri (0) ile üniversite mezunları (1) şeklinde oluşturularak 3 ayrı model tahmin edilmiştir. Tablo 7 incelendiğinde eğitimsiz ve eğitimli genç ișsizlerin modellendiği Model 1'de tüm açıklayıcı değişkenlerin bağımlı değișken üzerindeki etkisinin anlamlı olduğu görülmektedir. Model 2'de bağımlı değișken temel düzey kategorisi eğitimsiz veya ilköğretim mezunu genç işsizlerdir. Ege bölgesi değișkeni dișında diğer tüm değişkenler anlamlı tahmin edilmiştir. Model 3 incelendiğinde, tüm katsayıların anlamlı olduğu görülmektedir. Tüm değişkenler temelinde katsayılar karşılaştırılarak analiz bulguları değerlendirilmiştir.

Tablo 6: Brant ve Wald Testi Sonuçları

\begin{tabular}{|c|c|c|c|c|}
\hline \multicolumn{4}{|c|}{ Brant Testi Sonuçları } & \multirow{2}{*}{$\begin{array}{c}\begin{array}{c}\text { Wald } \\
\text { Testi } \\
\text { Sonuçları }\end{array} \\
\text { p-değeri }\end{array}$} \\
\hline Bağımsız değişkenler & Ki-kare & P-değeri & s.d. & \\
\hline İç Anadolu & $23,29 * *$ & 0,00 & 2 & 0,000 \\
\hline Ege & $11,56^{* *}$ & 0,00 & 2 & 0,001 \\
\hline Akdeniz & 0,19 & 0,91 & 2 & 0,640 \\
\hline Karadeniz & $23,24 * *$ & 0,00 & 2 & 0,000 \\
\hline Doğu Anadolu & $41,32 * *$ & 0,00 & 2 & 0,000 \\
\hline Güneydoğu Anadolu & $78,52 * *$ & 0,00 & 2 & 0,000 \\
\hline Cinsiyet & $152,1^{* *}$ & 0,00 & 2 & 0,000 \\
\hline Yaş & $514,17 * *$ & 0,00 & 2 & 0,000 \\
\hline Doğduğu ilde yaşama & $139,87^{* *}$ & 0,00 & 2 & 0,000 \\
\hline Medeni & $45,28^{* *}$ & 0,00 & 2 & 0,000 \\
\hline İşverene başvurma & 0,72 & 0,70 & 2 & 0,577 \\
\hline Yakınlardan rica & 0,65 & 0,72 & 2 & 0,975 \\
\hline İŞKUR'a başvurma & $13,58 * *$ & 0,00 & 2 & 0,001 \\
\hline Özel istihdama başvurma & $16,92 * *$ & 0,00 & 2 & 0,000 \\
\hline Tecrübe & $16,76^{* *}$ & 0,00 & 2 & 0,000 \\
\hline 2015 & $7,15^{* *}$ & 0,03 & 2 & 0,018 \\
\hline 2016 & 0,77 & 0,68 & 2 & 0,788 \\
\hline
\end{tabular}

Öncelikle bölge değişkenleri ele alınırsa, temel düzeyde Marmara bölgesi yer aldığı için diğer bölgeler Marmara bölgesi ile kıyaslanmaktadır. Bölge değişkenleri arasında Akdeniz bölgesi paralellik varsayımını sağladığı için tüm modellerde aynı fark oranı tahmin edilmiştir. Akdeniz bölgesinde yaşayanların Marmara'da yaşayanlara göre daha yüksek eğitim seviyesinde ișsiz olma olasılığı 0,85 kat daha azdır. Bölge bazında fark 


\section{AYDOS - Ç. DEMIR TOKER}

oranları açısından değerlendirme yapacak olursak, İç Anadolu bölgesinde yaşayanların Marmara'da yaşayanlara göre daha yüksek eğitim seviyesinde genç işsiz olma olasılığı model 1'de 2,28 kat; model 2'de 1,21 kat; model 3'te ise 1,14 kat daha fazladır. Genel olarak baktığımızda, Doğu ve Güneydoğu Anadolu bölgelerinde yaşayan genç işsizlerin Marmara'da yaşayanlara göre işsiz olma olasılığı daha düşüktür. İç Anadolu, Karadeniz ve Ege bölgelerinde yaşayan genç işsizlerin Marmara'da yaşayanlara göre daha yüksek eğitim seviyelerinde işsiz olma olasılıkları daha fazladır.

Cinsiyet değişkeni incelendiğinde, kadınların erkeklere göre eğitimli genç işsiz olma olasılığı model 1'de 1,29 kat; model 2'de 3,05 kat; model 3'te ise 3,02 kat fazla olduğu tahmin edilmiştir. Eğitim seviyesi arttıkça kadınların erkeklere göre eğitimli işsiz olma olasılığı artış göstermektedir. Kadınların işgücüne katılımı da erkeklere göre her eğitim seviyesinde azalış göstermektedir. Üniversite mezunları içerisinde bu fark azalsa da üniversite mezunu her dört kadından birinin işgücünde olmadığı ifade edilmiştir. (Yenilmez ve Kılıç,2018:62).

Yaş ilerledikçe gençlerin; Model 1'e göre eğitimli işsiz olma olasılıklarının eğitimsizlere göre 1,07 kat fazla olduğu, Model 3'e göre üniversite mezunu işsiz olma olasılıklarının diğerlerine göre 1,34 kat fazla olduğu saptanmıştır. Yaş arttıkça bireylerin iş bulma şansı ve bu konudaki umutları azalmaktadır (Karasoy vd.,2015:66). Bu nedenle gençlerin yaşı ilerledikçe işsiz olma olasılıkları artış göstermektedir.

Gençlerin medeni durumu da işsiz olma olasılığını etkilemektedir. Evlilerin, bekarlara göre eğitimli işsiz olma olasılığı model 1'de 0,30, model 3'te 0,18 kat daha düşüktür. Evli kişilerin bekarlara göre daha fazla sorumluluk sahibi olmaları nedeniyle ișsiz kalma sürelerinin daha kısa olduğu sonucuna varılmaktadır (Karasoy vd.,2015:65).

Doğduğu ilde yaşayanların, diğerlerine göre eğitimli işsiz olma olasılığı model 1'de 1,20 kat; model 3'te 0,51 kat daha düşüktür. Buradan, doğduğu ilde yaşayanların diğerlerine göre iş bulma konusunda avantajlı olduğu görülürken bu bulgunun aksine Karasoy ve arkadaşları yaptıkları çalışmada, insanların doğup büyüdükleri topraklarda çalışma sahalarının olmaması nedeniyle, sanayisi veya iş potansiyeli daha yüksek illere göç ettiğini ifade etmiştir (Karasoy vd.,2015:66).

Tecrübeli olan gençlerin, tecrübesizlere göre eğitimli ișsiz olma olasılığı model 1'de 0,43 kat; model 2'de 0,41 kat; model 3'te 0,34 kat daha düşüktür. Kısaca, tecrübeli olan genç işsizlerin istihdam edilme olasılıkları daha fazladır. İşverenlerin işe alım sürecinde deneyimli eleman talep etmesi nedeniyle tecrübesiz olmanın işsizliği arttırıcı bir unsur olduğu ifade edilmektedir. Ayrıca ișten çıkarılma söz konusu olduğunda, tecrübesiz gençlerin listenin başında yer alması gençlerin istihdaminı olumsuz etkilemektedir (Bayraktar ve İncekara,2013:25).

İş arama kanalları incelendiğinde, doğrudan işverene başvurma yöntemi ile iş arayanların diğerlerine göre eğitimli işsiz olma olasılığ 1,11 kat daha fazladır. Doğrudan işverene başvurma yöntemiyle iş aramanın genç işsizliğini azaltan bir unsur olmadığı sonucuna ulaşılmaktadır. İş bulma amacıyla genç işsizler arasında İŞKUR'a başvuranların başvurmayanlara göre işsiz olma olasılığ model 1'de 1,58 kat; model 2'de göre 1,34 kat; model 3 'te 1,20 kat daha fazladır. Buna göre, İŞKUR'un genç istihdamını olumsuz etkilediği sonucuna varılmaktadır. İş arama kanallarından bir diğeri olan özel istihdam kurumlarına başvurma değişkeni incelendiğinde, başvuranların başvurmayanlara göre işsiz olma olasılığ model 1'de 3,79 kat; model 2'de 3,21 kat; model 3'te 2,64 kat daha fazladır. Buraya kadar incelediğimiz iş arama kanallarının genç istihdamını arttıran bir etkisinin bulunmadığı açıkça görülmektedir. Son olarak, genç işsizlerin yakınlarından iş bulma konusunda ricada bulunmaları ise diğerlerine göre işsiz olma olasılıklarını 0,48 kat azaltmaktadır. $\mathrm{Bu}$ durumda, iş arama kanallarından sadece 
yakınlarından ricada bulunma yönteminin genç işsizlik olasılığını azalttığı sonucuna varılmaktadır. İŞKUR'un işgücü piyasa araştırmaları verilerinde, iş arama kanallarından İŞKUR ve yakınlardan ricada bulunmanın diğerlerine göre daha fazla tercih edildiği ifade edilmektedir. Analizde, eğitim durumuna göre işsizliği azaltan tek iş arama kanalının yakınlardan ricada bulunma olduğu saptanmıştır. İzmir İşgücü Piyasası Araştırmasının 2010 yılı raporuna göre, işverenler tarafından en çok tercih edilen işe alım kanalının, personel-akraba-eş-dost aracılığ olduğu açıklanmıștır (Kahraman ve Yaka,2016:129). İŞKUR tarafından yayınlanan talep yönlü işgücü piyasası araştırmalarının yıllara göre açık iş arama kanallarına bakıldığında; 2012, 2013 ve 2014 yıllarına ait veriler ortalamasında işverenlerin istihdam amaciyla personel arayıșında en fazla akrabaeş-dost kanalına başvurdukları görülmektedir (Tutar,2015:103).

\section{SONUÇ}

Genç işsizlik, günümüzde küresel boyutlara ulaşmış önemli bir sorundur. ILO'nun verilerine göre dünya genelinde genç işsizlik oranı toplam işsizlik oranının üç katından fazladır. Genç nüfusun hâkim olduğu dinamik bir ülke olan Türkiye'de ise gençlerin istihdamı konusunda yaşanan problemler, Türkiye ekonomisinin geleceğini önemli ölçüde etkilemektedir.

Bu çalışmada, son yıllarda gündemde olan genç işsizlerin, eğitim seviyelerine göre durumları incelenmiştir. Veriler, TÜIK'in uyguladığı hanehalkı işgücü anketinin 2014, 2015 ve 2016 yılları birleştirilerek elde edilmiş ve analiz yöntemi olarak genelleştirilmiş sıralı logit modeli kullanılmıştır. Bağımlı değişken; eğitimsiz, ilköğretim, lise ve üniversite mezunu kategorilerinden oluşan 4 eğitim seviyesine göre ele alınan genç işsizlerdir. Bağımsız değişkenler; bölge, cinsiyet, yaş, medeni durum, doğduğu ilde yaşama gibi demografik faktörlerin yanında, işverene başvurma, yakınlarından rica, İŞKUR'a bașvurma ve özel istihdama bașvurma gibi iș arama kanallarından ve iş tecrübesi değişkenlerinden oluşmaktadır. $\mathrm{Bu}$ değişkenler, eğitim seviyesine göre genç işsizlik üzerinde anlamlı etkileri olan değişkenlerdir.

Her eğitim seviyesinde bağımsız değişkenlerin etkilerinin aynı olduğunu ifade eden paralel eğimler varsayımı, bazı bağımsız değişkenler tarafından sağlanamamıştır. Bu nedenle sıralı lojistik regresyon yerine, bağımlı değişkenin düzeylerine göre farklı katsayı tahmini yapabilen genelleştirilmiş sıralı logit modeli kullanılarak analiz yapılmıştır. Bağımlı değișkenin dört kategorili olması nedeniyle, genelleştirilmiş sıralı logit yaklașımıyla üç ayrı model tahmini yapılmıştır. Her bir model için ayrı ayrı katsayı ve fark oranları tahmin edilmiştir.

Analizde, İç Anadolu, Ege ve Karadeniz bölgelerinde yaşayan gençlerin işsiz olma olasılığının fazla olduğu sonucuna ulaşılmıştır. Literatürde bölgeler arasında işsizliğin farklılık gösterdiği çalışmalar mevcuttur. $\mathrm{Bu}$ bölgelerin eğitimli genç işsizliğini arttırmasının nedeni sosyal ve ekonomik olguların yanında bölgelerin kendine özgü özelliklerinin de etkili olmasıdır. Bölgelerde genç işsizliğini arttıran unsurlar detaylı şekilde incelenmeli ve çözüme kavuşturulmalıdır (Sönmez ve Özerkek, 2018:310).

Cinsiyet açısından genç işsizlik incelendiğinde, kadınların erkeklere göre eğitimli genç işsiz olma olasılığının fazla olduğu görülmektedir. Literatürdeki diğer çalışmalarda da görülmektedir ki, dünya genç işsizlik oranı içerisinde kadınların sayısı erkeklerden fazladır (İzgi,2012:297). Bu durum, küresel boyutta işgücü piyasasında kadınların erkeklere göre dezavantajlı konumda bulunduğunun açık bir göstergesidir. Genç kadınların istihdamını arttıracak politikaları hayata geçirmek için gerekli adımların acilen atılması, genç işsizlik sorununun önemli boyutta çözüme kavuşmasına katkı 
sağlayacaktır. Genç işsizlerin doğduğu ilde yaşaması, doğduğu ilde yaşamayanlara göre eğitimli işsiz olma olasılığını azalttığı görülmektedir. Böylelikle, doğduğu ilde yaşayan bireylerin sosyal çevrelerini geliştirerek daha kolay iş bulabilecekleri fikri desteklenmektedir. Ayrıca eğitimli gençlerin iş arama konusunda yakınlarından ricada bulunması, istihdam edilmelerine olumlu katkı sağlamaktadır. Kısaca, sosyal çevreleri kuvvetli olan gençlerin diğerlerine göre işsiz kalma olasılığının daha düşük olduğu sonucuna ulaşılmaktadır. Literatürde işsizliğin sosyal dişlanmaya neden olduğuna dair çalışmalar mevcuttur fakat tam tersi durumda yani sosyal bağları kuvvetli olan bireylerin ișsiz olma olasılığının düşük olacağı sonucunu içeren bir çalışmaya rastlanmamıştır. $\mathrm{Bu}$ yönüyle literatüre katkıda bulunan bir sonuç elde edilmiştir. İş arama kanallarından işverene başvurma, İ̧̧KUR'a başvurma ve özel istihdam kurumlarına başvurma değişkenleri eğitimli genç işsiz olma olasılığını arttırmaktadır. Buradan anlaşılacağı üzere, iş arama kanalları eğitimli genç işsizlere iş bulma konusunda yeterli düzeyde yardımcı olamamaktadır. $\mathrm{Bu}$ nedenle gerekli kurumların gençlerin ihtiyaçlarına yönelik yeniden yapılandırılması gerekmektedir. Türkiye'nin elinde bulundurduğu genç işgücü avantajını en verimli şekilde kullanması, ülkenin geleceği açısından önemlidir. $\mathrm{Bu}$ nedenle gençlere ve genç işgücüne gereken önemin verilmesi gerekmektedir. Son ylllarda, tüm dünyada ve Türkiye'de genç işsizliğin giderek artması, genç işsizlik kavramının çözüme ulaştırılması gereken ciddi bir sorun olduğunu göstermektedir. Genç işsizliğini etkileyen tüm unsurların tespit edilmesi, bu doğrultuda gereken önlemlerin alınması ve iyileştirmelerin yapılması gerekmektedir. Genç işsizliğini etkileyen unsurlardan en önemlisi, eğitim sisteminden kaynaklanan sorunlardır. Eğitim sisteminde nicelik olarak yapılan yenilik ve iyileștirmelerin, nitelik olarak yapılmasının gerekliliği oldukça önem arz etmektedir. Mevcut eğitim sisteminde öğrencilere verilenler ile işgücü piyasasında çalışanlardan beklenenler arasında bir uyumsuzluk olduğu görülmektedir. Gençlerin, işgücü piyasasının ihtiyaç duyduğu nitelikte eğitim alması hem bireye, hem topluma, hem de ülke geleceğine yapılacak önemli bir yatırımdır. Bu nedenle, özellikle eğitimli genç işsizliği konusunda hükümetin eğitim sisteminde yapacağı düzenlemeler ve genç işgücüne yönelik uygulayacağı istihdam politikaları genç işsizlik sorunun çözümü için gereken öncelikli adımlardır. Ayrıca, yeni girişimler devlet ve toplum tarafından desteklenmeli, yeni istihdam alanlarının oluşumu sağlanmalıdır.

\section{KAYNAKÇA}

Abdioğlu, Z., Albayrak, N. (2018). Genç işsizlik, eğitim ve ekonomik büyüme. Global Journal of Economics and Business Studies, 7(13), 8-20. Erişim adresi https://dergipark.org.tr/en/download/article -file/511343

Arl, E. , Yıldız, Z. (2014), Parallel lines assumption in ordinal logistic regression and analysis approaches. International
Interdisciplinary Journal of Scientific Research,1(3): $\quad$ 8-23. Erişim adresi https://www.researchgate.net/publication/3 11903359

Ay, S. (2012),Türkiye'de işsizliğin nedenleri: istihdam politikalarl üzerine bir değerlendirme. Yönetim ve Ekonomi, 19(2): 321-341.

Erişim adresi 
https://dergipark.org.tr/en/download/article -file/146108

Audas, R., Berde, E. , Dolton, P. (2005), Youth unemployment and labor market transitions in hungary. Education Economics, 13(1): 1-25. Erişim adresi https://doi.org/10.1080/096452904200032 5180

Bayrak, R. , Tatlı, H. (2016), Short and long term analysis of some factors effecting youth unemployment in turkey. Theoretical and Applied Economics, 23(3608): 229-242. https://doi.org/10.46928/iticusbe.768646

Bayraktar, S. , İncekara, A. (2013), Türkiye'nin genç işsizliği profili. Çalışma İlişkileri Dergisi, 4(1): $\quad$ 15-38. $\quad$ Erișim adresi https://dergipark.org.tr/tr/pub/cider/issue/ 29527/316948

Brant, R. (1990), Assesing proportionality in the proportional fark model for ordinal logistic regression. Biometrics, 46(4): 1171-1178. https://doi.org/10.2307/2532457

Choudhry, M. T. , Marelli, E. ve Signorelli, M. (2010). Youth unemployment rate and impact of financial crises. International Journal of Manpower, $\quad 33(1)$ : 76-95. https://doi.org/10.1108/014377212112125 38

Çondur, F., Bölükbaş, M. (2014), Türkiye'de işgücü piyasası ve genç işsizlik-büyüme ilişkisi üzerine bir inceleme. Amme İdaresi Dergisi, 47(2): 77-93.

Fu, Vincent, K., (1998). Estimating generalized ordered logit models. STATA Technical Bulletin StataCorp LP, 8 (44).

Fulerton, A. S., Xu, J.(2012). The proportional fark with partial proportionality constraints model for ordinal response variables. Social Science Research, 41(2012): 182-198. https://doi.org/10.1016/j.ssresearch.2011.09 .003

Fulerton, A. S., Xu, J.(2018). Constrained and Partial Adjacent Category Logit models for ordinal response variables. Sociological Methods \& Research, 47(2): 169-206. https://doi.org/10.1177\%2F0049124115613 781

Günaydın, D., Çetin, M. (2015), Genç işsizliğin temel makroekonomik belirleyicileri: ampirik bir analiz. Pamukkale Üniversitesi Sosyal Bilimler Enstitüsü Dergisi, 22: 17-34. Erişim adresi

https://dergipark.org.tr/en/pub/pausbed/iss ue/34744/384232

Gündoğan, N. (1999), Genç işsizliği ve avrupa birliği'ne üye ülkelerde uygulanan genç istihdam politikaları. Ankara Üniversitesi SBF Dergisi, 54(1): 63-79. Erişim adresi https://dergipark.org.tr/en/download/article -file/36293

International Labour Office (2017), global employment trends for youth 2017: paths to a better working future. International Labour Organization, Geneva. Erişim adresi https://www.ilo.org/wcmsp5/groups/public /---dgreports/---dcomm/--publ/documents/publication/wcms_598669. pdf

International Labour Office (2018), World employmet social outlook trends:2018. International Labour Organization, Geneva.

İzgi, B . (2012). Genç işsizliği ve eğitim ile olan ilişkisi. Elektronik Sosyal Bilimler Dergisi ,11(41): 295-310. Erişim adresi https://dergipark.org.tr/tr/pub/esosder/issu e/6155/82718

Harris, M. N. (1996). Modelling the probability of youth unemployment in australia. Economic Record, 72(217), 118129.https://doi.org/10.1111/j.14754932.1996.tb00946.x

Hilbe, J. (2009), Logistic Regression Models, CRC Press, Boca Raton.

Karabıyık, İ. (2009). Avantaj ve dezavantajları ile genç işsizliğinin değerlendirilmesi. Erzincan Üniversitesi Hukuk Fakültesi Dergisi, 13(3-4): 293-320. 
Karasoy, D., Tutkun, N. A., ve Bulut, V. (2015). Türkiye'deki işsizlik süresini etkileyen faktörler. Uluslararası Yönetim İktisat ve İșletme Dergisi, 11(26), 57-76. https://doi.org/10.17130/ijmeb.2015.11.26.8 28

Kleinbaum, D. G., Klein, M. (2010), Logistic regression: a self-learning text. Third Edition, Springer, Newyork.

Long, J. S. (1997), Regression Models for Categorical and Limited Dependent Variables. Sage Publication, California.

Long, J. S., Freese, J. (2001). Regression Models For Categorical Dependent Variables Using Stata. Stata Press, Texas.

Lynch, L. M. (1985). State dependency in youth unemployment: a lost generation? Journal of Econometrics, 28(1),

71-84.

https://doi.org/10.1016/0304-

4076(85)90067-3

Mlatsheni, C., Rospabe, S. (2002). Why is youth unemployment so high and unequally spread in south africa?. Development Policy Research Unit Working Paper, 2(65).

Mroz, T. A., Savage, T. H. (2006). The long-term effects of youth unemployment. The Journal of Human Resources, 41(2): 259-293. doi: 10.3368 / jhr.XLI.2.259

Murat, S., Şahin, L. (2011). Nedenleri ve sonuçları bakımından gençler arasında yaygınlaşan işsizlik. Sosyoloji Konferansları Dergisi, 44: 1-48. Erişim adresi https://dergipark.org.tr/en/pub/iusoskon/is sue/9548/119251

Mütevellioğlu, N., Zanbak, M., Mert, M. (2010), İşsizlik, Üniversiteli Gençlik ve Gelecek: Bir Alan Araştırması Bulguları, C.Ü. İktisadi ve İdari Bilimler Dergisi, 11(1): 207-229.

Narayan, P. K., Smyth, R. (2004), Crime Rates, Male Youth Unemployment and Real İncome in Australia: Evidence from Granger Causality Tests. Applied Economics, 36(18): 2079-2095. https://doi.org/10.1080/000368404200026 1842
Ören, K., Şahverdioğlu, H. (2016). Türkiye'de genç işsizliği ve genç işsizliğinin giderilmesinde aktif istihdam politikaları. Gençlik ve Spor Bakanlığı Gençlik Araştırmaları Dergisi, 4(1): 5-37.

Petreski, M., Mojsoska-Blazevski, N., ve Bergolo, M. (2017). Labor-market scars when youth unemployment is extremely high: evidence from macedonia. Eastern European Economics, 55(2), 168-196. https://doi.org/10.1080/00128775.2016.126 1631

Riphahn, R. T. (2000). Residantial location and youth unemployment:the economic geography of school to work transitions. Population Ecomics:Family, Haousehold and Work:273293. https://doi.org/10.1007/978-3-64255573-2_14

Sayın, F. (2011). Türkiye'de 1988-2010 döneminde eğitim ve büyümenin genç işsizliğine etkisinin analizi. Dokuz Eylül Üniversitesi Sosyal Bilimler Enstitüsü Dergisi, 13(4): $\quad 33-53 . \quad$ Erişim adresi https://dergipark.org.tr/en/pub/deusosbil/is sue/4626/63108

Sungur, O. (2015). 2000 sonrası türkiye ekonomisi: büyüme, enflasyon, işsizlik, borçlanma ve diş ticarette gelişmeler. Toplum ve Demokrasi,9(19-20): 243-269. Erişim adresi

http://www.onursungur.com/files/makale/ makale-2015-toplumdemokrasi.pdf

Sönmez, F. D. ve Özerkek, Y. (2018). Türkiye'de bölgesel genç işsizliğin belirleyicileri. Marmara Üniversitesi İktisadi ve İdari Bilimler Dergisi, 40(2), 297-318. DOI: 10.14780/muiibd.511033

Taşçı M. H. ve Tansel A. (2005). Youth unemployment duration in turkey, METU Studies in Development, 32(December): 517545. Erişim adresi https://open.metu.edu.tr/bitstream/handle/ 11511/58583/66-66-1-PB.pdf

Tutar, K. (2015). Türkiye işgücü piyasasında iş arama kanallarının niteliği. İş ve Hayat, 1(2), 
93-106. Erişim adresi https://dergipark.org.tr/en/pub/isvehayat/is sue/29032/310460

Umoru, D., ve Evelyn, O. O. N. (2018). Econometric analysis of unemployment and poverty in nigeria: the role of education. Journal of Academic Research in Economics, 10(1), 94-110.

Kahraman, R. Yaka, Y. (2016). İşgücü piyasasında iş arama kanallarının etkinliği. Proceedigs E-Book 2, 125.

Yenilmez, F., Ve Kılıç, E. (2018). Türkiye'de işgücüne katılma oranı-işsizlik oranı ilişkisi: cinsiyet ve eğitim düzeyine dayalı bir analiz. Eskişehir Osmangazi Üniversitesi İktisadi ve İdari Bilimler Dergisi, 13(2), 55-76. DOI: 10.17153/oguiibf.410254

Yentürk, N. ve Başlevent, C. (2007). Türkiye genç işsizliği. Gençlik Çalışmaları Birimi Araştırma Raporu. No:2, İstanbul.

Williams, R. A. (2006). Generalized ordered logit/ partial proportional fark models for ordinal dependent variables. Stata Journal, 6(1): 58-82.

Williams, R. A. (2006). Generalized ordered logit/ partial proportional fark models for ordinal dependent variables. Stata Journal, 6(1): 58-82.

Winkelmann, R. (1996). Employment prospects and skill acquisition of apprenticeship-trained workers in German. ILR Review, 49(4), 658-672. https://doi.org/10.1177\%2F0019793996049 00405

İnternet Kaynakları

Baltaş, A. (2017), Değişen Dünyada Eğitim Anlayışı ve Değişmeyen Değerler, Erişim adresi https://www.acarbaltas.com/degisendunyada-egitim-anlayisi-ve-degismeyen-degerler/ 
M. AYDOS - Ç. DEMIR TOKER

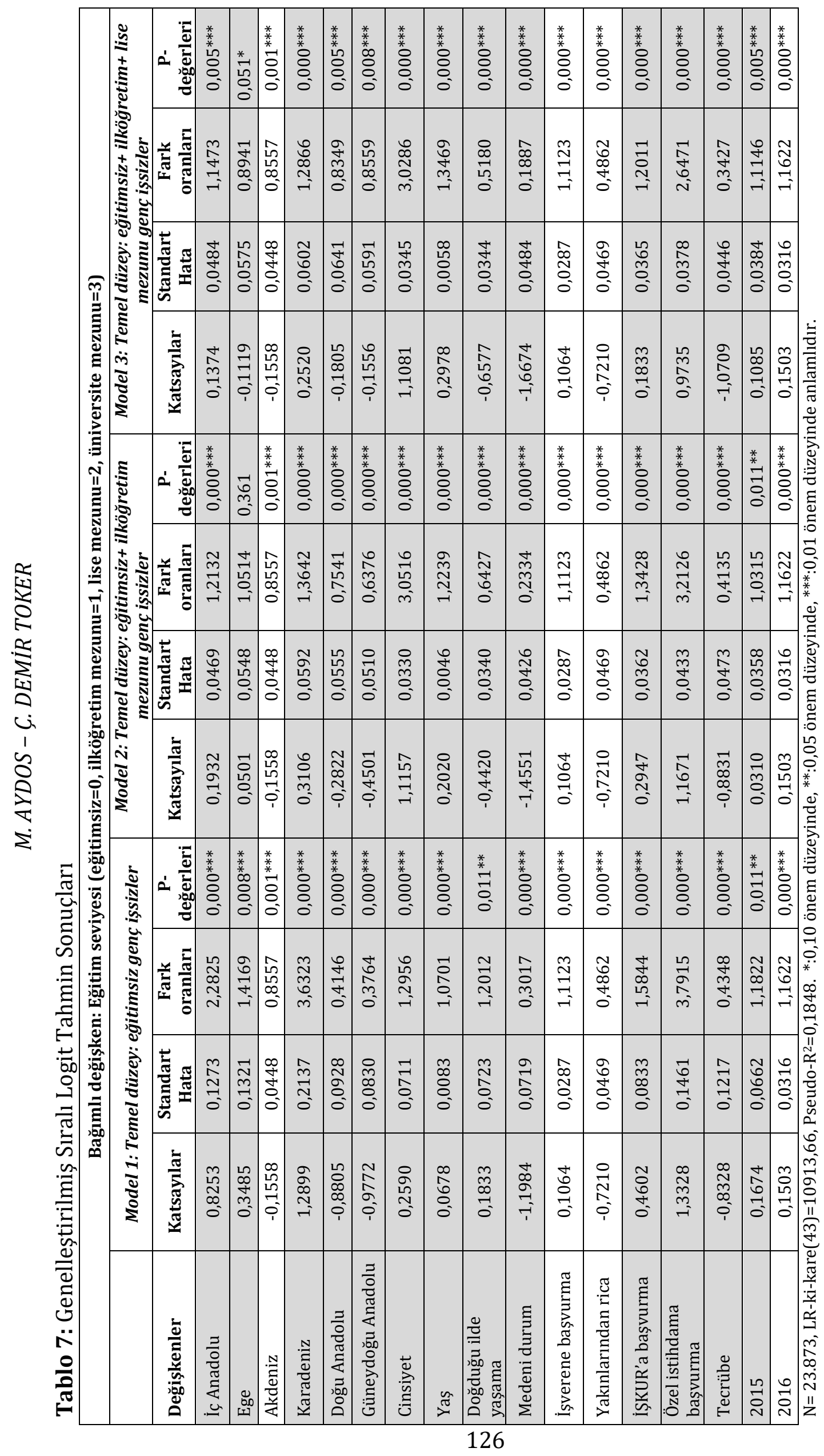

